\title{
Rachel Fensham
}

\section{Trajectories of the 'Dead Heart': Performing the Poetics of (Australian) Space}

In this paper Rachel Fensham returns to the writings of Gaston Bachelard in order to examine the poetics of space from a non-European horizon. Spatial metaphors, such as the 'dead heart', that feature in historical and geographical imaginaries also evoke phenomenological dimensions in Australia. Postcolonial space however disturbs cartographic concepts in the mises en scène of theatrical performance. Fensham analyzes two recent performances that radically reimagine the poetics of (Australian) space through the movement trajectories of walking and falling. Rachel Fensham is a Professor of Dance and Theatre Studies at the University of Surrey. Her book with Denise Varney, The Dolls' Revolution: Australian Theatre and Cultural Imagination (Australian Scholarly Publishing: 2005) examines the influence of women playwrights on mainstream Australian theatre, and her current research examines transmission and transnationalism in choreographic practice.

GASTON BACHELARD, in The Poetics of Space, invites recognition of the ways in which interior and imaginative landscapes, such as cupboards, houses, and forests, resonate in the phenomenological worlds of poets, novelists, explorers, and artists. Rich in its metaphoric dimensions, Bachelard's poetics however symbolize a European and gendered consciousness which is geographically and historically particular. Postcolonial writers and artists, playwrights, and choreographers have to locate their imaginings simultaneously in this European poetics and in landscapes that belong to different climates, geologies and peoples. The spatial poetics of Australia, for example, include the familiar signs of Western European settlement such as the suburb, city, house and garden, but they also encompass the wide spaces of desert and beach with their own distinctive phenomenology, linguistics and history. Rather than polarize these systems of representation, I want to suggest in this essay that new Australian performance enfolds two spaces into one, both the suburb and the edge of darkness where the desert begins. In this poetics of space - peculiar to Australia and other frontier nations - the suburb and desert belong to one another, even if they remain alien and unreconciled in the national psyche or political landscape. From this complex mix of belongings, different trajectories through space, such as not walking falling, become important to the postcolonial imagination.

In terms of cultural history, the suburb and desert have developed their own genres and modes of representation. In the twentieth century, the suburb as a social space has spawned a distinctive national literature and been eulogized in film, song, art, theatre and television. ${ }^{i}$ It is argued that the mise en scène of Australian theatre has privileged domestic naturalism in playwright David Williamson's inner city satires (from The Club to Brilliant Lies) and Murray-Smith's family dramas (Honour and Love Child). On the other hand, recent Australian dance from Garry Stewart and Gideon Obarznek has located dance aesthetics in a cartoon reality not dissimilar to Ren and Stimpy. The full presence of the suburb, with its ubiquitous heterosexuality, mundanity and whiteness, in these productions excludes the vastness of the desert and the littoralness of ocean. As a result, the ideological shape of the dramaturgy serves a kind of false consciousness in White Australia because it cannot represent structures of feeling that exist beyond the suburban 
horizon.i ${ }^{\text {ii }}$ More recently, some bold theatrical experiments, particularly in Aboriginal performance, outdoor spectacle and other epic productions, such as the Australian Opera's Voss (1986) and Batavia (2001), have tried to engage with the 'immensity' and complexity of a wider Australian spatial poetics.

The discourse on the desert as Australia's 'dead heart' however derives from a much earlier period. The metaphor is not geographic, but linguistic and metaphoric, political and psychological, and was coined during the nineteenth century history of exploration. For Edward Eyre, Charles Sturt and Peter Warburton, the centre of Australia was a space of emptiness and desolation. Sturt could give neither European proper noun nor Aboriginal name to a desert that appeared like an ocean, 'a perfect sea of dunes' trackless' as far as the eye can see.' ${ }^{\text {iii }}$ This image of a desert void was reinforced in the twentieth-century by scientist Cecil Madigan who renamed the Arunta Desert, or 'Great Ribbed Desert', after his financial backer Simpson, simultaneously erasing both its aboriginal and topographical significance with a white man's name. His appellation of the term 'Dead Heart' was to become entrenched in popular white consciousness as the space at the centre of Australia. ${ }^{\text {iv }}$ Today, the concept of an empty and hostile centre serves repressive purposes in political mythology. Its apparent distance from 'civilization' legitimates an ongoing misuse and abuse of place and persons in the desert, including the British atomic bomb tests in the 1950s on Aboriginal Land at Maralinga, and the present immigration policy of detaining Middle Eastern refugees in the Woomera Detention Centre. Perhaps it is not surprising that films such as Priscilla Queen of the Desert and Rabbit Proof Fence, or paintings by Fred Williams, allow vast stretches of red sand to signify a kind of desolate abandonment in the national psyche.

How white and black histories co-exist in these different political and cultural imagin aries remains one of the most troubling poli tical projects for Australians. Recent cultural theorists, such as Jennifer Rutherford and Ghassan Hage, have analysed the conflation of language, psychoanalysis, and national identity in both art and political discourse as constitutive forces in Australia's political terrain.4 They offer ways to understand a social landscape that makes an elderly Lebanese man afraid to cross the street (Hage), or a political move ment that uses the 'ordinary' as a weapon (Rutherford), by reading them as a national unconscious that cannot yet conceive alter native modes for thinking responsibly about tolerance or the complexity of difference. In this context, the concept of the 'dead heart' in Australia acquires an almost compulsory psychopathology that erases the living or lived space of the desert by insisting upon its dual purpose as an interiority that must be both violent and violable. While the relationship between desert and suburb exists as an opposition in most sys tems of logic (governmentality, geography, population, etc.), I want to suggest that, phenomenologically, this 'interior of the country' with its vast, apparently limitless, horizons can intensify the depths of inner 
space, and the interior states of those who live within this landscape. Bachelard's con ception of the poetic realm is that rational thought cannot account for all modes of perceiving reality, and that images open up the subjective dimensions of knowledge to new ways of understanding the real. This model of an imaginative epistemology depends on the sort of breaks, discontinuities, and ruptures that have become important to poststructural theories and methodologies. A rupture that disturbs the layering of images in the psyche becomes available for sustained analysis.

Although most oft cited for his writings on the domestic, small pockets of human experience, in the last part of The Poetics of Space, Bachelard considers 'immensity'. When we experience, recall, or daydream spaces such as ocean, forest, and desert, we enter what he calls 'one-dimensional space', in which the materiality and its proportions - or if you like, their extensions - become unified.5 We are in the midst of the ocean or desert as much as at their periphery once we enter them.

For this reason, according to Bachelard, the imaginative power of 'intimate immensity' draws us into ourselves more intensely. It permits the experience of 'motionlessness' since without edge, definition, and horizon we have an increase of being, 2 an expanded, intensified awareness of experience. But this 'immensity', I will argue, requires a falling into space that is very different from more Cartesian, carto graphic, or quotidian movements in space. Falling into the desert, I suggest, produces a trajectory that destabilizes the colo nial and modernist topographic imagination. Through performance, Australian dance and theatre offers insights into how these relations between the corporeal, the spatial, and the historical, in one orientation become displaced towards another.

In two recent productions, the co-existence within a field of observations of Australian space has multiple resonances.

Fiction, choreographed by Phillip Adams and Rebecca Hilton, shows a fantasy desert becoming a psychotic domestic space, while Still Angela, written and directed by Jenny 
Kemp, moves from a kitchen chair to the trauma of the desert as interior space. For Bachelard, the poetic imagination makes 'the function of the real and the function of the unreal . . c co-operate'.6 The trajectory in these two works moves between two worlds, the real and unreal, the material everyday and the imaginary universe. There is an imaginative crossing of verticalhorizontal and spatio-temporal paths that function, as Patrice Pavis suggests, like vectors to link unrelated rhetorical figures with one another. Vectors rapidly shift the spectator's perspective, and allow the material arrangements of one time-space to translate into the metaphor or image of another.7 As a performative mode, the tangible sensory effects of dislocation and relocation between horizons and places register on conscious ness. In Fiction and Still Angela, vectoral dynamics assist the spatial poetics of a dead heart to become an alternative epistemology.

\section{Non-Fiction: from Desert to Suburb}

The Melbourne-based contemporary dance company BalletLab presented Fiction in Sep tember 2004.8 The performance was divided into two independently choreographed sequences, both theatrically abstract yet meta phorically Australian. In the first half, choreographed by Phillip Adams, a painted scrim shows a surreal Arabian desertscape - all sky blues, harems and oases - evocative of Hollywood orientalist fantasy. The second half, choreographed by Hilton, according to the programme examines 'epic family struggle and intimate personal interaction'.9 Set within a mediated postmodern frame in which an older man sits watching television, the Technicolor image of the desert is filled with suburban nostalgia for an exotic Middle East, far distant from present political conflicts. His flimsily dressed white dancers stitch intricate patterns with their feet in a series of kitsch motifs that resemble the figures on a packet of Camel cigarettes or the picture on a Turkish carpet.

The transition between this unreality, and Hilton's scorched vision is arresting. With the galloping horses and dancing harem gone, one female dancer slithers with a lizardlike movement under the painted backdrop. 
The surrogate TV spectator, actually Adams the choreographer, slowly draws back the fictional desert curtain and walks away with his hat covering his face. He looks shameful and ashamed. Two groups of dancers (each two women and one man) wearing orange costumes appear on either side of the central axis, but they blur into the bright orange walls and floor of the bare studio.10 (Fig. 1) Primarily interested in abstract dance, Hilton admits to an obsession with the ways in which the family operates as the 'undeni able, inevitable structure'; and following her 'surrender' to the spatial story of Australian suburbia she made this work.11 Without delay, Hilton interrogates this reality by inserting orange picket fences down the central axis of the space. This shift in perspective exposes what is implicit, yet absent, in Adams's work. Behind the desert fantasy is a divided suburban consciousness; and on either side of the fence we are in the copycat domestic space of the nuclear family.

The disarticulated choreography exagger ates the effects of suburban interiority on the body. The women squash themselves against the wall surface, forming odd points of contact, and the man's head lolls about as 3

they push him around. When the 'father' eventually opens his eyes, he looks per plexed. Marionette-like, each group builds a pyramid, pushing the 'girl' up onto the scaffolding of the couple. (Fig. 2) In this 'house', the two girls replicate each other's movements. As they step out from the wall, they watch, hand over mouth, as if horrified, at the simu lated sex of the 'parents' who have fallen on the floor. As Hilton writes:

The relationships are like clockwork, the under lying sadness muted by the strangeness of the orange, the complexity and density of the choreo graphy and the yukky determinedly jolly music. The 'girl', enveloped by the 'ordinary un kind ness' of her parents, observes the collapsing of adult social relations into adulterous repe tition. In response, she abuses herself - on the one hand, we see her stuffing herself with marshmallows, and on the other, she adopts the self-imposed autism of the chronic I-pod user. Sonically, weird rasp ing noises are syncopated with the familiar 
strains of a Neil Diamond song. The bodies are like plasti -

cine, disjointed and collapsing under pres -

sure, while the movements seem desultory

and impersonal. The suburban

bodies of this piece suffer from the inner violence

that occurs when stagnant affection dissipates

into compulsive sexual gratific -

ation or masturbatory solitude. If the interior, in all its over-familiarity,

is a space riven with this kind of violence, then its pain

has to be kept below the horizon of consci -

ous ness in Australia's emotional landscape.

Hilton says of this work:

I conceived of my half of the piece (programme)

as a depiction of an emotional winter. Working in

that large orange space in the heat of summer,

emotional desert began to feel more like it, and it

became an incredibly rich place to collect these

ideas I'd been exploring for years. The emotional

resonances of space, the distance between the

characters and the variety of ways those distances

could be traversed.

At the same time, the piece exposes the

exterior, as a stark orange consciousness of nation.

The sunburnt walls and bodies rupture the masculine hori -

zon, with its artificially fabricated landscape of

pristine desert, and lead to the estrangement of

suburbia. In the flailing gestures, we find a nuclear family, buttressed by government

policy, yet pressed flat and exhausted of

significance. And with not walking falling

bodies, the dancers create a 'nowhere' space

which is disturbingly Australian. The extended spatial contiguity of

the choreography changes the visible hori -

zon of the performance space, and allows

paranoid perceptions to be felt in the interior desert of the

suburban house.

The Unreal: from Suburb to Desert

Jenny Kemp's production of Still Angela

premiered at the Malthouse Theatre in 2002

and toured nationally in 2004.12 By way of

contrast with Hilton's choreography, Kemp's

theatre creates a mise en scène of the 'unreal'

revealed through memory, dream, and

fantasy. With an ongoing artistic interest in the

lived interiority of the feminine, she produces a stage

world in which various elements - such as text, music and actions cons -

tructed discretely - flow

together.

Her characters also exist in inner and outer

realities. Although Bachelard's phenomeno -

logy of space might be gendered masculine, his

conception of a 'greater elasticity

of daydreaming' that draws house and

universe together is pertinent to 
the feminine dynamics of Still Angela.13 Sitting in a daydream, Angela's trajectory between kitchen and desert takes place sym bolically through a train journey that in part reflects a desire for self-realization and in part investigates the interiority of Australia. (Fig. 3) When she steps off the train for a walk, she describes the Simpson Desert as the 'dead heart', but is surprised to find the desert teeming with life:

Many people think a desert is a desolate and lonely place. But in the desert, by moonlight, animals that are nowhere to be seen during the day, are everywhere. 14

4

Like many gestures in Kemp's productions, the walk signifies entry into a state of consciousness that is not mimetic of reality, but rather represents a repressed reality into which Angela later falls.

In his writing about 'intimate immensity', Bachelard describes the poetic experience of a vast space as one that is intensified 'by the scale of its proportions'. While resistant to the political order that has determined the desert as empty, or void, Kemp, like Bachelard, thinks of the desert as a place which reconciles distances between inner and outer experience:

Angela ... was drawn to the desert by a paradoxical need/feeling of cluttered fullness and emotional emptiness (death). This was when she started to wake up, come out of trance. The sifting that needed the space/travel to have the space/time to do this work. She becomes both empty and dead, yet full and alive. 15

The sounds of buzzing, of horses hooves fading away and of drawn-out musical notes, transform the space aurally from the suburb to the desert.

This noisy yet sparse spatial poetics articulates a potent political and psychic anxiety for white Australians, perhaps particularly, for women. As Kemp reflects:

There is of course the desert in the centre of Aus tralia, which sits inside the country and inside our selves, whether you go there or not, and I think in some ways I had built up a kind of fear of going there (especially alone) - perhaps there is a touch of agoraphobia in Australia.16

In Kemp's terms, being in the desert explodes the myth of the 'dead heart' as outside threat. Instead of opposing the desert to the spaces of the known, she transports the spec tator into repressed memories of Australia. 
When the shadow of

actor Mark Minchinton (playing the train

guard) falls against a portal showing a

filmed desert landscape - red sand, bushes

and deep blue sky - he suddenly steps into

a missing black history.

The actor's own hidden Aboriginal his tory was part of the research subtext during the rehearsal process:

My mother would take us on long trips across the Nullarbor when I was very young and she would pull right off the road, driving sometimes for a long time straight into the desert at ninety degrees to the road to make camp. Now my mother was always a bit fearful, but it was probably mainly a fear of meeting Aboriginal people, since we were often on Aboriginal reserves. The irony of this, given my then unconfirmed Aboriginal heritage, is fairly overwhelming.17

The palpable spatiality of this fear is actively registered in a scene of the perfor mance called 'Trauma'. In it, the 'decimation' at the heart of the interior is amplified with a woman's hysterical laughter turning into a hiccoughing scream. In the dark ness of a night sky figures from Angela's childhood find themselves falling, whether asleep or dead or 'assembling and reassem bling their intestines'.18 Choreographed by Helen Herbertson, the actors fold and fall into the ground while orienting themselves to the 'enormity of the space'. There are the 'facts' of the desert, its emptiness and its lack of consciousness in white imagination, to be located within the work. But to cite written histories and aboriginal testimony, or the reality of police brutality in Alice Springs and the abstract beauty of Central Desert painting, would reinscribe opposed horizons. To not impose a landscape, the trajective of the production hovers in its reflection of experience.

After the journey into a 'decimated' interiority, Angela sits on her kitchen chair with a renewed sense of place:

Outside me is the night

sky the universe

the big picture

on the train

past the trees

past the hills

into the desert

past oceans of landscape

5

into the suburbs

the backyards 
the backyard

the house

the rooms

the floors the walls

chairs tables

the people

then back out again

out the window

up out into

nowhere

everywhere

the ant

the horse

the human.19

Transformed by an outside, Angela has become con -

nected with both the expanses of the 'universe'

and the smallest creature on

her kitchen floor. In this altered conscious -

ness, the scale of spaces and things appears

relational rather than axiomatic, and the psy -

che and the social become integrated.

According to Bachelard, we need an incredible

expansion of space in order to intensify the

field of perception: 'All the universe that

bears the mark of the desert is annexed to

inner space.' 20 Through this annexation, the

diversity of images in a poem or a perfor -

mance becomes united in the vastness of 'inner

space'. In Still Angela, with the movement of

not walking but rather falling, the use of light-shadow

and the contrast between cacophony and

breath, the spectator can concentrate on the experience of multiplicity

in the desert. The intensified loss of hori -

zons therefore portends the density of Australian space.

Phenomenology of Not Walking Falling

In his discussion of the writer Phillippe Diolé, Bachelard refers to the actions of 'wandering' in

the desert, however this notion is far too romantic to encompass the fraught experience of

traveling in the Australian desert. Perhaps he is rather closer to the mark when he writes that

Pierre Loti 'questioned the immense horizon of sand'.FN As these two performances

demonstrate, the interior-exterior

relation of suburb and desert has an uncertain topography and

trajectory; it also requires different spatial practices of

bodily movement. If an expanded correspondence between the spatial imagin -

ary of suburb and desert is 'psychically innovating', then I propose that movement connections between the

feet and heart also choreograph the

phenomenology of postcolonial Australia. FN

Embodied space is mobile, transitory and fragile in its

physical reality; spatial metaphors transmute under the pressure of the foot. For this

reason, the multidimensionality of walking

can be physical and aesthetic as well as

articulate and political; it manufactures and

organizes space by subjecting movement to 
the order of the pathway. When we walk, the feet take us forward, rolling slowly, yet linear and horizontal, helped by the eyes leading us on. Falling by way of contrast is an action in vertical space, it is not topographical, architectural nor structural. Like walking, it is a physical practice, a psychic orientation, and a political understanding that suddenly transforms the stability of a particular hori zon. When we fall, the eyes lose focus; the feet fold over one another, the body is suddenly indirect and malleable, cha otic and subject to gravity. The kinesthetic awareness may be barely conscious, but these actions physically register the poetics of a space, bringing place into being through bodies that traverse them. The interior of white Australian con sciousness takes its shape in the desert, I would suggest, by being open to this experience of falling from one reality to another, from one state of being to another. It happens through 'not walking falling'. FN

Walking and falling, of course, have their own spatial theorists. For Michel de Certeau, the trajectories of people walking in the city provide a counter rhetoric to hierarchical systems of power under modernism. 'Pedes trian movements,' he argues, ' are not local 6 ized, it is rather that they spatialize.'FN Urban passers-by coordinate pathways as they move between the discrete positions of A and B. Their improvisatory steps lead to a proliferation of spatial stories, or conditions of possibility, within an established architecture. Thus the everyday practices of walking constitute 'habitable' spaces resistant to the forgetting of corporate structure. FN Walking in the city invigorates space by filling it with all manner of ambulatory bodies. It can be imagined singly or collectively: the solitary walker carves out an intense spatial meditation and a mass of bodies walking together gathers energy like a herd. For this reason, protest marches have been effective, because they gather momentum on a horizontal plane, taking possession of the streets.

Walking, especially with feet in sand, can be disrupted by falling, thus leading to a different consciousness.

The postmodern theorist Paul Virilio writes: I think that we can't see the world any other way than as a fall into the world. This is not a meta phor. Our human vision depends on gravity, that is to say on the fact that one does or does not fall. Horizontal movement, walking, is a way of falling 
from one foot onto the other, and in the same way, the perspectival vision that we have of the hori zon is linked to the fact that we fall into the horizon.22

For Virilio, a change in horizon represents a practical shift that includes a subjective awareness

of the weight of the body and its

relationship to knowledge. Instead of seeing,

the experience of falling cannot happen without becoming

deeply aware of the weight of the bodily

mass, of the internal organs, and feeling the

peripheral loss of coordination. But through

falling a subject can experience the trajectory,

not in a pathway, but as a terrestrial, who belongs to the earth

with all the responsibility that implies.

As Virilio explains:

Philosophically speaking, between the subject and

the object what's always missing is the trajectory....

We have to reinvent the being of trajectory, to re -

discover its meaning, the trajective or trajectivity.

The being of the trajectory can be reinvented if we

restore gravity's force, its reality-producing power.

We are beings of gravity.

Falling thus represents both a rupture and a

shifting of perspective that establishes an

almost involuntary opening towards the

ground. In terms of speech acts, walking is the volume

given the locutionary act whereas falling is the density of an utterance. They have different

ehtical consequences. And if we consider

the performative production of space it is rarely a neat arrange -

ment, like walking. Performance is more often, as

Virilio suggests, like free fall; it is trajective

and potentially reality producing.

The dance theorist Gabrielle Brandstetter

argues that falling in postmodern dance

represented an epochal shift in Western aes -

thetics. In Western concert history, the concept of

falling first appeared in modern dance when

dancers began to use the idea of fall and

recovery to work with a floor surface rather

than stay suspended above it. But it was not

until the experiments of New York post -

modern dance that a conception of palpable

weight began to govern the experimental possibilities

of movement.

Falling, according to Brandstetter, instigates 'the

paradox of disturbance' that can be present

even in the most ordinary movement of

walking'.23 It is the point at which the body

slips out of control in which the potential for

another movement arises. This shift in align -

ment has nothing to do with alienation, nor

is it about parody and its related conven -

tions. Rather, Brandstetter suggests that in 
the conjunction between the known and the repeatable as habit, the point of unlearning can be contained - so it is the function of falling to precipitate the unknown, 'foreign' movement in the body and for a new aes thetic principle to emerge.

Instead of a dialectics that regards the old, the known, as the object of criticism, spatial theory 7

suggests that not walking falling allows for a change without direction and without a stated object to be present in the poetics of performance.24 The diagram below sug gests moreover that this phenomenological shift in spatial poetics moves from the colonial hori zon of Australian space to that of a post colonial ex-centricity.

[Diagram to come.]

The ethical heart

In the two productions I have analysed, the trajectory from suburb to desert is active and embodied, although Hilton's work is more mimetic and descriptive and Kemp's more symbolist. In different ways, interior space, understood as psychic and social, is connected with exterior space un derstood as political and geographic through the human body walking and falling. Falling out of suburbia therefore requires a displacement of the organs, a movement in a sense into free fall towards the desert.

This dynamic has, I would argue, implica tions for a symbolic corporeality that makes the heart an essential organ of nation. If we think of this bodily organ as a living thing in the country, then the 'dead heart' invokes a disturbing mode of national consciousness. Let us recall the hanging head of the man who pulled back the curtain in Hilton's (non)-fiction; he displays an affect without support, a kind of embarrassed deadness towards others.

A lack of political heart, or shame about the desert, is exemplified in political events. Faced with the erosion of indigenous Australian rights to social services and political representation, the celebrated Aboriginal footballer and activist Michael Long began walking to Canberra in December 2004. He was demanding proper attention should be paid to his people, but the question emblazoned on his T-shirt - 'where is the love?' - was embarrassing. When he stopped the walk half-way, 
falling if you like, many

politicians tried to dismiss his Long

Walk as a symbolic gesture. But this walking

'the blackfella way' with a mob of friends was

a departure from suburbia towards the desert

which refused to allow the void to become despair.

8

Earlier that same year, Cecilia Rau, the middle-aged Australian daughter of

German immigrants, walked away from her

suburban family. Suffering from delusions,

Federal police locked her up as an illegal alien in a

desert detention centre. This fall into an abject state echoes

the trauma of Still Angela. What is remarkable in

these two events is that a citizen's walk out of the suburb becomes so

easily a fall by not walking from A to B.

These spatial trajectories show how ordinary people also slip

into the 'dead heart', the spaces of wilful era -

sure in the nation.

Performance pieces illuminate the sensu -

ous poetics of Australian space without set -

ting out to be political interventions. As they define

paths in an exterior landscape, both intimate and vast,

theatrical productions can open up an interior

that is palpable because embodied. I would argue

that Hilton and Kemp have produced a spatial poetics

in which an audience will experience an

Australia that is at times deeply disturbed,

- catatonic in some respects, traumatized in

others - when fearful of falling.

Travelling towards the dead heart is to fall

into consciousness of a European social and

imaginative failure to acknowledge an indi -

genous or postcolonial ecology of space. An

altered poetics of space is felt, then, at the

point where the earth rushes towards us, the

heart enters the mouth, and we have to pull

the cord - perhaps when white Australians

meet the desert? Dropping from fiction to

fact in an ontological sense changes the

horizon, and leads towards a different sense

of Australia. By not walking falling, falling

could be an act of love.

Notes and References

EDIT 1. In postwar Australia, the propinquity of middle class consciousness to brutal modernity was asserted in the suburb, as immortalized in Robin Boyd's The Australian Ugliness (Melbourne: Cheshire, 1961).

ADD FN. The problematic tensions of staging Australian space have been addressed in two recent books that include multiple examples of theatre and performance that interrogates the history of different landscapes. See Joanne Tompkins, Unsettling Space: Contestations in Contemporary Australian Theatre. (London: Palgrave, 2006); and Gay McAuley, Unstable Ground: Performance and the Politics of Place. (Brussels: P.I.E. Peter Lang, 2006).

EDIT 2. Luis Hercus, Flavia Hodges, Jane Simpson, ed., The

Land is a Map: Placenames of Indigenous Origin in Australia

(Canberra: ANU and Pandanus Books, 2002).

EDIT 3. Philip Jones, 'Naming the Dead Heart: Hillier's Map

and Reuther's Gazetteer of 2,468 Placenames in North- 
Eastern Australia', in Hercus et al., op.cit.

4. Roslynn Haynes, Seeking the Centre: the Australian

Desert in Literature, Art, and Film (Cambridge: Cambridge

University Press, 1998).

5. Jennifer Rutherford, The Gauche Intruder: Freud,

Lacan, and the White Australian Fantasy (Melbourne: Mel -

bourne University Press, 2000), and Ghassan Hage, White

Nation: Fantasies of White Supremacy in a Multicultural

Society (Annandale: Pluto Press, 1998).

6. Gaston Bachelard, The Poetics of Space, trans.

Maria Jollas (Boston: Beacon Press, 1969),

7. Op. cit., p. xxxi.

8. Patrice Pavis, Analyzing Performance, trans. David

Williams (Ann Arbor: University of Michigan Press,

2003), p. 240.

9. Fiction presented by Balletlab, Chunky Move

Studios, 19-29 August 2004.

10. Rebecca Hilton, programme note, Fiction.

11. Performed by dancers Tim Harvey, Brooke

Stamp, and Joanne White; and Ryan Lowe, Claire Peters, and Carlee Mellow.

12. Rebecca Hilton, email correspondence, 21 January

2005.

13. Still Angela, 10 April 2002, with the following

cast: Lucy Taylor, Natasha Herbert, Margaret Mills,

Felicity McDonald, Simon Wilton, Mark Minchinton,

and Ros Warby.

14. Bachelard, p. 51.

ADD FN. Bachelard, p. 205.

EDIT 15. Describing the Simpson Desert, Angela quotes her high school atlas and speculates on its

connotations as a 'dead heart'. Jenny Kemp, Still Angela

(Sydney: Currency Press, 2002), p. 15.

16. Jenny Kemp, email correspondence, November

2004.

17. Op. cit.

ADD 18. Mark Minchinton, Extract 'Noon, Wed, 24 September 2003' from Void: Kelleeberrin Walking. National Review of Live Arts, Midland, WA and School of Contemporary Arts, Edith Cowan University, 2003.

19. Kemp, p.17-18.

20. Op. cit., p. 46.

ADD FN. Bachelard, p. 204.

ADD FN. Op. cit., p.206

21. Quoting Diole on 'annexation', Bachelard, p.

204-5.

DELETE footnote . Edward S. Casey, The Fate of Place: a Philosophical

History (Berkeley: University of California Press, 1997).

ADD FN Michel de Certeau, The Practice of Everyday Life, (Berkeley: University of California Press, 1984), p. 97.

ADD FN Op. cit., p. 106.

23. Paul Virilio, in Laurence Louppe, ed., Traces of

Dance: Drawings and Notations of Choreographers, trans.

Brian Holmes and Peter Carrier (Paris: Editions Dis Voir,

1994), p. 37.

ADD FN. I borrow this term in part from the name of the Australian rock band Not Drowning

Waving.

EDITED 20. Gabriele Brandstetter and Hortensia Volickers, ed., ReMembering the Body,

trans. Andrea Scrima and Rainer Emig (Ostfildern-Ruit:

Hatje Cantz, 2000), p. 122.

24. Op. cit., p. 126

DELETE 25. 'The commands to which a state subjects its

citizens go way beyond repression in the face of the

trans gres sion of law but get instantiated in the very

incorporation of what spans the productive citizen from

the regimentation of labour to the identification of

desire.' Critical Moves: Dance Studies in Theory and Politics

(Durham: Duke University, 1998), p177.

DELETE 26. The 2003 federal election was won by the Howard

Liberal government on the promise that interest rates

for housing loans would not increase.

DELETE 27. Alice Cummins, email correspondence, April 
2005.

DELETE 28. Op. cit.

Titles for Illustrations

Fig. 1 From desert to suburb: Fiction 2004.

Photo Jeff Busby, permission Phillip Adams, Balletlab.

Fig. 2 House-scaffolding: Fiction 2004.

Photo Jeff Busby, permission Phillip Adams, Balletlab.

Fig. 3 Kitchen and desert: Still Angela 2002.

Photo Jeff Busby, permission Jenny Kemp.

${ }^{\mathrm{i}}$ In postwar Australia, the propinquity of middle class consciousness to brutal modernity was asserted in the suburb, as immortalized in Robin Boyd's The Australian Ugliness (Melbourne: Cheshire, 1961).

ii The problematic tensions of staging Australian space have been addressed in two recent books that include multiple examples of theatre and performance that interrogates the history of different landscapes. See Joanne Tompkins, Unsettling Space: Contestations in Contemporary Australian Theatre. (London: Palgrave, 2006); and Gay McAuley, Unstable Ground: Performance and the Politics of Place. (Brussels: P.I.E. Peter Lang, 2006).

iii In Luis Hercus, Flavia Hodges, Jane Simpson (eds.) The Land is a Map: Placenames of Indigenous Origin in Australia (Canberra, ANU and Pandanus Books, 2002).

iii Philip Jones, 'Naming the Dead Heart: Hillier's Map and Reuther's Gazetteer of 2,468

Placenames in North-Eastern Australia', in Hercus et al. op.cit.

${ }^{\text {iv }}$ Roslynn Haynes, Seeking the Centre: The Australian Desert in Literature, Art and Film (Cambridge: Cambridge University Press, 1998). 